\title{
Cutting Wood Origin and Indole Butyric Acid Influence Success of Liberica Coffee Cuttings (Coffea Liberica W. Bull Ex. Hier)
}

\author{
Novie Pranata Erdiansyah ${ }^{1 *}$, Inung Pinata Rokhani ${ }^{2}$, and Sriyanto Waluyo ${ }^{2)}$ \\ ${ }^{1)}$ Indonesian Coffee and Cocoa Research Institute, Jl. PB Sudirman 90, Jember, Indonesia \\ ${ }^{2}$ Agriculture Faculty, Gadjah Mada University, Jl. Flora, Bulaksumur, Yogyakarta, Indonesia \\ ${ }^{*}$ Corresponding author: noviepranata@gmail.com \\ Received: 1 June 2016 / Accepted: 21 September 2016
}

\begin{abstract}
Liberica coffee can be grown in peatland and has a specific flavor. To anticipate high demand of Liberica coffee product, it is very important to support the availability of high quality seedlings that need effective multiplication method of superior genotypes. This study aimed to investigate the effect of indole-butyric acid (IBA) concentration and cuttings wood origin and their interaction in the success of Liberica coffee cuttings. This research was held at Kaliwining Experimental Station, Indonesian Coffee and Cocoa Research Institute, designed using randomized complete block in factorial with two factors consisted of cutting wood origin and concentration of IBA. First factor was cuttings wood origin consisted of the tip, middle, and base, while second factor consisted of the concentration of IBA i.e. 0, 1500, 3000, and $4500 \mathrm{ppm}$. The results showed that the end of the shoots aged of 4-6 months were better part of shoot for cutting material. Percentage of the grown cutting reach up to $80 \%$, while the middle and base part of shoots had a fairly low percentage of grown cutting, less than $43 \%$. IBA a tended to increase rooted cuttings number. Combined treatment between cuttings material origin in the middle part with the IBA concentration of $4500 \mathrm{ppm}$ showed the best root growth.
\end{abstract}

Keywords: Liberica coffee, cuttings, budwood, entres, indole butyric acid, origin

\section{INTRODUCTION}

Compared to other coffee product, Liberica coffee is a coffee species which product is less popular compared to Arabica and Robusta. Liberica coffee has good adaptation in peatlands (Hulupi, 2014). Indonesia has large area of peat land concentrated from Sumatera to Kalimantan. The peatland areas are currently not utilized optimally, especially for cultivating Liberica coffee which is largely propagated generatively using seeds that the performance of the plants were so vary due to segregation process that less productive and less uniform of the bean quality. Liberica is a cross polli- nated plant therefore it is necessary to use appropriate vegetative propagation techniques i.e. propagation using stem cuttings (Gatut \& Mubiyanto, 1998). Similar method was utilized for Robusta coffee because both types have similar properties.

Propagation method utilizing stem cuttings is also widely used mainly because it is easily implemented (Sumirat et al., 2013). Nevertheless, experiments using cuttings method on Liberica coffee showed unsatisfactory results due to its low survival rate and root formation. Therefore stem cutting implementation on Liberica coffee needs to be given additional applications in form of 
plant growth regulator (PGR) which is nonnutrient organic compound. It is applied in small dosage to encourage, inhibit or regulate plant physiological processes. PGR is only effective when used on a certain amount of dosage. High concentration level could damage plants through cell division, excessive callus, and preventing shoots and roots growth. Utilizing less than optimum concentration would be ineffective. One factors that affect stem cutting success is growth regulators usage. According to Hartmann et al. (1990), auxin is the most instrumental plant growth regulator used in stem cutting. IBA, a type of synthetic auxin, has proven to increase root formation. Propagation by plant cuttings is also known as immersion method. Determining PGR concentration depends on the length of material soaked and the types of plants used.

Plant type plays a role in utilizing plant cutting. According to Arifin \& Nurhayati (2005), plant cuttings ability to form roots depends on the species. There are species that easily grow roots and while other types possess low rate of root formation. Some types are incapable to grow root, despite being given special treatment. Coffee types naturally possess high root formation, nevertheless there are types which easily grow roots at stem shoot (tip cuttings) and some at the stem base (stem base cutting). Tamin et al. (2016) mentioned that IBA concentration level and soaking time affected survival rate of tembesu (Fagraea fragrans) cutting. The IBA concentration of $500 \mathrm{ppm}$ and two hours soaking time produced best survival rate.

The purpose of this study was to determine the effect of planting material origin and varying IBA concentration on the success of plant cuttings performed on Liberica coffee and its interactions. This information is also expected to assist in understanding Liberica coffee plant propagation using plant cuttings method.

\section{MATERIALS AND METHODS}

The study was conducted at Kaliwining Experimental Station of ICCRI (45 m asl. and D rainfall type). Materials used are Liberica coffee orthotropic branches aged for 4-6 months. The material was derived from parent trees in the budwood garden grown in Kaliwining Experimental Station. The materials used were taken from some of the mother plants and divided equally in each treatment. Plant growth regulators was IBA (Indole Butyric Acid) using water solvent. Quick dip method was used in the treatment. The study was arranged $3 \times 4$ factorial randomized block design with three replications. The first factor was cutting material i.e. tip, middle and base. The second factor was IBA applied i.e. 0 ppm, 1500 ppm, $3000 \mathrm{pm}$, and $4500 \mathrm{ppm}$. Each cuttings segment were planted in $1.25 \mathrm{~m} \mathrm{x} 5 \mathrm{~m}$ plastic cover beds and cover frame made of bamboo in order to cover plant cuttings from high light intensity as well as to speed up optimal cuttings growth. Planting medium was a mixture of soil, fine sand and manure in 2:1:1 $(w / w)$ ratio. The mixture was previously fumigated and left for a week before planting phase. Watering was done once a week by opening the cover for a moment then closed it again. For pest and disease control, insecticides and fungicides were applied when an attack occurred. The variables were percentage of callused cuttings, callus diameter, callus cuttings percentage, number of roots, root length, root formation and survival rate. Observations was carried out after five months. The data was analyzed by its variance (ANOVA) with a 95\% confidence level. If there was a significant difference be continued using Duncan test at 5\% significance level. 


\section{RESULTS AND DISCUSSION}

Plant growth is a process of increasing cell numbers and plant size, which can be observed in various plant organs such as buds, callus or roots. It is derived from several variables observations such as the number of shoots, callus, and diameter. Another important para- meter is plant cuttings root formation percentage. Some plant cutting possessing small survival and root formation rate. Therefore propagation methods requires growth regulator application such as auxin to stimulate root formation.

Roots play an important role in determining vegetative propagation success, especially when employing plant cutting methods. Root formation/growth is done by young roots located in stems (root primordial) and callus. Callus is unorganized tissue which responds to cover plant wounds. In propagation plant cutting, callus formed on cut parts, covering the wound. According to Wiratri (2005), callused cutting characteristics are its sprouts. However, callus formation in cut plants parts does not guarantee root formation to take place. It is not able to absorb nutrients contained in the media. Alongside plant shoot, it was absorb food reserves in trunk and ultimately accelerate nutrients exhaustion before plant cuttings grow roots.
Table 1 exhibits significant differences between treatments of plant cutting in middle and base part. Base cutting utilizing 4500 ppm IBA exhibited significantly different result compared other plant cuttings methods and IBA concentration. Similarly, number of callus, callus diameter (Table 2) resulted from base part cutting and $4500 \mathrm{ppm}$ IBA resulted in lowest callus diameter. On the other hand, cutting without IBA application possessed the highest callus diameter. There are adequate carbohydrates which promote material plant survival supported by leaf photosynthesis will be used to encourage shoot and root formation. It starts with first callus growth as the beginning stages of primordial roots initial growth process.

Root formation occured in the cutout section because that section will produce callus which was then differentiated to form primordial root. Plant cutting success rate is determined by measuring root formation percentage (Table 3).

PGR application has a tendency to produce higher plant cutting percentage. It could be seen from highest stem base cuttings root formation rate data in stem base cutting treatment utilizing 4500 ppm IBA concentration (Table 3). As Winarno (2001) reported, utilizing IBA root regulators will produce

Table 1. Percentage of Liberica coffee cutting producing calli as affected by IBA concentration and cutting wood origin

\begin{tabular}{lcccrc}
\hline \multirow{2}{*}{ Cutting wood origin } & \multicolumn{5}{c}{ IBA concentration } \\
\cline { 2 - 6 } & $0 \mathrm{ppm}$ & $1500 \mathrm{ppm}$ & $3000 \mathrm{ppm}$ & $4500 \mathrm{ppm}$ & Mean \\
\hline Tip & $42.86 \mathrm{a}$ & $35.71 \mathrm{a}$ & $26.19 \mathrm{~b}$ & $21.43 \mathrm{bc}$ & 31.55 \\
Middle & $21.43 \mathrm{bc}$ & $7.14 \mathrm{f}$ & $19.05 \mathrm{bcd}$ & $16.67 \mathrm{~cd}$ & 16.07 \\
Base & $19.05 \mathrm{bcd}$ & $9.52 \mathrm{ef}$ & $14.29 \mathrm{cf}$ & $11.9 \mathrm{def}$ & 13.69 \\
\hline
\end{tabular}

Notes: Data followed by the same letter are not significantly different at $5 \%$ significance level according to DMRT.

Table 2. Callus diameter ( $\mathrm{mm}$ ) of Liberica coffee cuttings as affected by cutting wood origin and IBA concentration

\begin{tabular}{lccccc}
\hline \multirow{2}{*}{ Cutting wood origin } & \multicolumn{5}{c}{ IBA concentration } \\
\cline { 2 - 5 } & $0 \mathrm{ppm}$ & $1500 \mathrm{ppm}$ & $3000 \mathrm{ppm}$ & $4500 \mathrm{ppm}$ & $\mathrm{Mean}$ \\
\hline Tip & $1.47 \mathrm{a}$ & $1.14 \mathrm{def}$ & $1.26 \mathrm{~b}-\mathrm{e}$ & $1.18 \mathrm{c}-\mathrm{f}$ & 1.26 \\
Middle & $1.32 \mathrm{a}-\mathrm{d}$ & $1.09 \mathrm{ef}$ & $1.39 \mathrm{ab}$ & $1.37 \mathrm{abc}$ & 1.29 \\
Base & $1.44 \mathrm{ab}$ & $1.09 \mathrm{ef}$ & $1.47 \mathrm{a}$ & $1.02 \mathrm{f}$ & 1.26 \\
\hline Notes: & Figures followed by the same letter(s) are not significantly different according to Duncan multiple range test at 5\% \\
& significance level.
\end{tabular}


greater effect when applied on cocoa clones resulted in low to moderate success rate.

PGR's success depends on several factors such as plants age and environmental factors involving light intensity and humidity (Sudrajad \& Widodo, 2011). Low root formation percentage is considered to be influenced by environmental factors such as light intensity and air moisture rate received in cutting environment. Based on Table 4, stem tip part cuttings applied with IBA 4500 and 0 ppm concentration resulted in significantly different result with the various usages of plant cuttings materials and IBA concentration. The large number of root in stem base cutting is due to carbohydrate accumulation contained in this section. Based on Orthosiphon aristatus plant cutting research (Kastono et al., 2005), stem base cutting (sections 3-6) form root faster and easier because it has high $\mathrm{C} / \mathrm{N}$ ratio. This is supported by Hartmann et al., 1990 and Pamungkas et al., 2009 who found that low $\mathrm{C} / \mathrm{N}$ inhibit root formation initiation.

Length of root formation in plant cutting exhibits PGR capability in performing its role as root growth regulator or inhibitor. Based on Table 5, it appears that the plant cutting's root length was significantly different from tip cuttings applied with IBA concentration of $0 \mathrm{ppm}$ and $4500 \mathrm{ppm}$, and in section cuttings treated with $0 \mathrm{ppm}$ and $1500 \mathrm{ppm}$. Stem base and section cuttings treated with concentration of $4500 \mathrm{ppm}$ IBA have a highest root number on the other hand middle section cutting treated with 1500 ppm IBA had the lowest root number. This result seemed to be influenced by genetic factors and plant type, such as Sansiviera (Ramadiana, 2008) and Adenium (Harjanti, 2005 cit. Sulistiana, 2011) which showed that middle section

Table 3. Percentage of rooted cuttings of Liberica coffee as affected by cutting wood origin and IBA concentration

\begin{tabular}{lccccc}
\hline \multirow{2}{*}{ Cutting wood origin } & \multicolumn{5}{c}{ IBA concentration } \\
\cline { 2 - 6 } & $0 \mathrm{ppm}$ & $1500 \mathrm{ppm}$ & $3000 \mathrm{ppm}$ & $4500 \mathrm{ppm}$ & M ean \\
\hline Tip & $9.52 \mathrm{c}$ & $14.29 \mathrm{bc}$ & $16.67 \mathrm{abc}$ & $14.29 \mathrm{bc}$ & 13.69 \\
Middle & $11.9 \mathrm{c}$ & $11.9 \mathrm{c}$ & $9.52 \mathrm{c}$ & $19.05 \mathrm{ab}$ & 13.10 \\
Base & $16.67 \mathrm{abc}$ & $11.9 \mathrm{c}$ & $11 . \mathrm{c}$ & $21.43 \mathrm{a}$ & 15.48 \\
\hline Notes: & Figures in followed by the same letter(s) are not significantly different according to Duncan multiple range test at 5\% \\
& signifcance level.
\end{tabular}

Table 4. Root number of Liberica cuttings as affected by cutting wood origin and IBA concentration

\begin{tabular}{lccccc}
\hline \multirow{2}{*}{ Cutting wood origin } & \multicolumn{5}{c}{ IBA concentration } \\
\cline { 2 - 6 } & $0 \mathrm{ppm}$ & $1500 \mathrm{ppm}$ & $3000 \mathrm{ppm}$ & $4500 \mathrm{ppm}$ & Mean \\
\hline Tip & $1.33 \mathrm{~b}$ & $2.00 \mathrm{ab}$ & $1.67 \mathrm{ab}$ & $1.33 \mathrm{~b}$ & 1.58 \\
Middle & $1.67 \mathrm{ab}$ & $1.67 \mathrm{ab}$ & $2.00 \mathrm{ab}$ & $2.67 \mathrm{a}$ & 2.00 \\
Base & $1.67 \mathrm{ab}$ & $2.00 \mathrm{ab}$ & $2.33 \mathrm{ab}$ & $2.33 \mathrm{ab}$ & 2.08 \\
\hline Notes: Figures followed by the same letter(s) are not significantly different according to Duncan multiple range test at 5\%
\end{tabular}
signifcance level

Table 5. Root length $(\mathrm{cm})$ of Liberica coffee cuttings as affected by cutting wood origin and IBA concentration

\begin{tabular}{lccccc}
\hline \multirow{2}{*}{ Cutting wood origin } & \multicolumn{5}{c}{ IBA Concentration } \\
\cline { 2 - 6 } & $0 \mathrm{ppm}$ & $1500 \mathrm{ppm}$ & $3000 \mathrm{ppm}$ & $4500 \mathrm{ppm}$ & Mean \\
\hline Tip & $4 \mathrm{bc}$ & $4,34 \mathrm{ab}$ & $4,67 \mathrm{abc}$ & $3,97 \mathrm{bc}$ & 4.24 \\
Middle & $4,03 \mathrm{bc}$ & $3,93 \mathrm{c}$ & $4,3 \mathrm{abc}$ & $4,97 \mathrm{ab}$ & 4.31 \\
Base & $4,45 \mathrm{abc}$ & $4,32 \mathrm{abc}$ & $4,73 \mathrm{abc}$ & $4,89 \mathrm{a}$ & 4.60 \\
\hline Notes: & Figures followed by the same letter(s) & are not significantly different according to Duncan multiple range test at 5\% \\
& signifcance level.
\end{tabular}




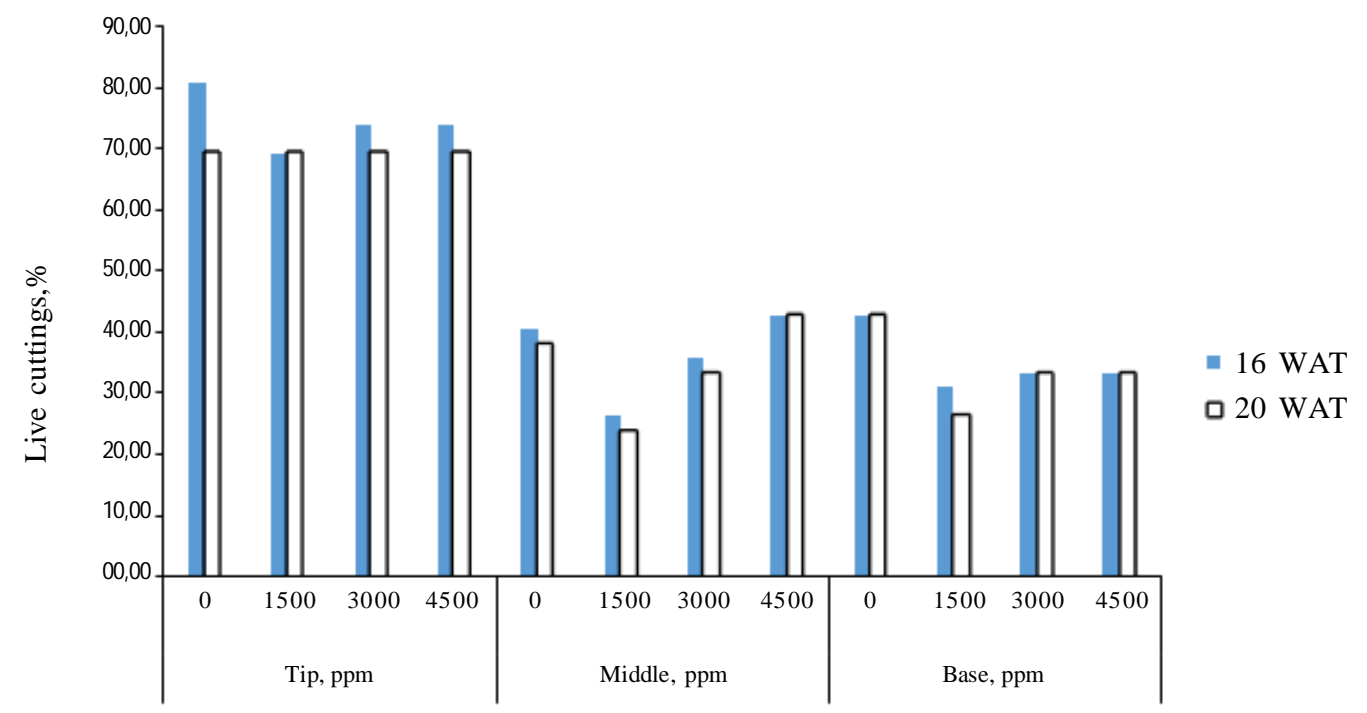

Figure 1. Percentage of live cuttings of Liberica coffee 16 and 20 weeks after treatment (WAT) as affected by cutting wood origin and IBA concentrations

stem cutting resulted in good root formation which was exhibited from number of adventitious roots formed.

In general, IBA had no significant effect on increasing successfull Liberica coffee cutting percentage. Plant cutting success rate is believed depend on plant's ability to grow new shoots and roots. Plant cuttings being able to grow and develop are characterized by shoot and root formation in observed plants. The early symptoms include budding stems and shoots. Budding shoots are expected to produce auxin which stimulates root formation on the cuttings. In general, the percentage of sprouted Liberica coffee plant cuttings is relatively low. Plant cutting's survival rate between 16 to 20 weeks after planting decreased (Figure 1). It is caused by lack of moisture marked by cambium stem turning brown and dried. Plant cutting dryness is presumably caused by high air temperature inside the containment; therefore the cuttings moisture evaporates fast and consequently become drier. Plant cuttings lack of moisture was expected due to lack of food reserves.
Cutting the shoots too much without having followed by root formation resulted in plant running out of food reserves. Plant cuttings are not able to produce their own food from photosynthesis yet. According to Prastowo et al. (2006), good cuttings process enable plant cuttings to grow roots. Should root formation does not occur, leaves and buds will undergo shedding to reduce evaporation.

\section{CONCLUSIONS}

Orthotropic shoot tip of Liberica coffee aged for 4-6 months was appropriate part to be used in cuttings process. Survival rate reached $80 \%$, while the middle and base section had less than $43 \%$ survival rate. IBA applied in Liberica cuttings exhibited no significant effect to increase successful cuttings percentage but there was an interaction between IBA and material origin. Application IBA had a tendency to produce higher root formation. The best treatment was obtained from combined treatment of base part cutting with 4500 ppm IBA. 


\section{REFERENCES}

Arifin, H.S. \& Nurhayati (2005). Pemeliharaan Taman. Edisi Revisi. In: Modul Melakukan Perbanyakan Bibit dengan Cara Vegetatif No Kompetensi. TAN. HI.02.009.01. PT Penebar Swadaya. Jakarta.

Gatut-Supriyadji \& B.O. Mubiyanto (1998). Beberapa alternatif teknik perbanyakan vegetatif tanaman kopi. Warta Pusat Penelitian Kopi dan Kakao, 14, 139- 145.

Harjanti, S. (2005). Pertumbuhan StekSetek Adenium Melalui Pendinginan, Asal Bahan Setek, Penggunaaan Pupuk Daun, dan Komposisi Media. Skripsi, Fakultas Pertanian, Universitas Negeri Sebelas Maret. Surakarta.

Hartmann, H.T.; D.E. Kester \& F.T. Davies (1990). Plant Propagation Principles and Practices. Prentice-Hall Inc., Englewood Cliff., New Jersey.

Hulupi, R. (2014). Libtukom: Varietas kopi Liberica anjuran untuk lahan gambut. Warta Pusat Penelitian Kopi dan Kakao, 26, 1- 6.

Kastono, D.; H. Sawitri \& Siswandono (2005). Pengaruh nomor ruas setek dan dosis pupuk urea terhadap pertumbuhan dan hasil kumis kucing. Jurnal Ilmu Pertanian, 12, 56- 64.

Pamungkas, F.T.; S. Darmanti \& B. Raharjo (2009). Pengaruh konsentrasi dan lama perendaman dalam supernatan kultur bacillus Sp.2 Ducc-Br-K1.3 terhadap pertumbuhan steksetek horisontal batang jarak pagar (Jatropha curcas L.). Jurnal Sains \& Matematika, 17, 131- 140.

Prastowo, N.H.; J.M. Roshetko; G.E.S. Maurung; E. Nugraha; J.M. Tukan \& F. Harum (2006). Teknik Pembibitan dan Perbanyakan Vegetatif Tanaman Buah. World Agroforestry Centre (ICRAF) \& Winrock International, Bogor.
Ramadiana, S. (2008). Respon pertumbuan setek lidah mertua (Sansevieria trifasciata var. Lorentii) pada pemberian berbagai konsentrasi IBA dan asal bahan tanam. Prosiding Seminar Hasil Penelitian dan Pengabdian Masyarakat, Universitas Lampung., Bandar Lampung.

Schmidt, F.H. \& J.H.A. Ferguson (1951). Rainfall Types Based On Wet And Dry Period Ratios For Indonesia With Western New Guinea. Verhandelingen. No. 42, Kementerian Perhubungan Djawatan Meteorologi dan Geofisika, Jakarta.

Sulistiana, S. (2011). Respon Pertumbuhan Daun Setek Lidah Mertua (Sansevieria parva) pada Pemberian Zat Pengatur Tumbuh Sintetik (Rootone-F) dan Asal Bahan Setek. Laporan Penelitian Madya, Fakultas MIPA, Universitas Terbuka.

Sumirat, U.; F. Yuliasmara \& Priyono (2013). Analisis sifat-sifat pertumbuhan setek pada kopi Robusta (Coffea canephora Pierre.). Pelita Perkebunan, 29, 159- 173.

Tamin, R.P. \& S. Napisah (2016). Pengaruh konsentrasi indole butyric acid (IBA) dan lama perendaman terhadap pertumbuhan setek Tembesu (Fagraea fragrans Roxb.). Jurnal Penelitian Universitas Jambi: Seri Sains, 18, 69- 80.

Winarno, H. (2001). Kemampuan berakar setek beberapa klon kakao dan responsnya terhadap perlakuan bahan pemacu perakaran. Pelita Perkebunan, 17, 55- 63.

$* * 0 * *$ 